\title{
CONCENTRATION AND CHEMICAL STATE OF COPPER IN SYNOVIAL FLUID AND BLOOD SERUM OF PATIENTS WITH RHEUMATOID ARTHRITIS
}

\author{
BY \\ WILLIAM NIEDERMEIER* \\ From the Division of Rheumatic Diseases, Department of Medicine and Department of Biochemistry, \\ University of Alabama Medical Center, Birmingham, Alabama
}

It was recently reported (Niedermeier, Creitz, and Holley, 1962) that the copper concentration in synovial fluid from patients with rheumatoid arthritis was elevated by a factor of three. The observation that copper could not be dialysed out of either "normal" or rheumatoid synovial fluid led to speculation concerning the nature of the compounds with which this element was associated. It was shown (Schmid and MacNair, 1956) by immunoelectrophoresis that synovial fluid from patients with joint effusions contained ceruloplasmin. This paper presents for the first time quantitative determinations of ceruloplasmin in synovial fluid and shows that the increase in copper concentration in synovial fluid of patients with rheumatoid arthritis is due almost entirely to an increase in ceruloplasmin concentration.

\section{Methods}

\section{Collection of Specimens}

Specimens of blood were collected by venepuncture from nineteen "apparently normal" volunteers and from 21 patients with rheumatoid arthritis. After coagulation, the blood was centrifuged and the serum promptly removed from the clot and analysed for copper and ceruloplasmin. Synovial fluid was aspirated from the knee joints of six "normal" volunteers, twelve cadavers in which death was due to various causes but had no evidence of connective tissue disease, and 23 patients with rheumatoid arthritis with effusion.

Fluid was collected from one knee joint only of the patients with rheumatoid arthritis; the volume aspirated ranged from 3 to $30 \mathrm{ml}$. (mean for 23 specimens $18.8 \mathrm{ml}$.).

Fluid from both knee joints of the normal volunteers was aspirated and pooled; the volume aspirated ranged from 1.8 to $4.0 \mathrm{ml}$. (mean for six specimens $2.6 \mathrm{ml}$.).

Fluid from both knee joints of the cadavers was like-

* Supported by Grants from the National Institutes of Arthritis and

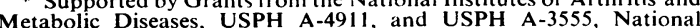
Metabolic Diseases, USPH A-4911, and USPH A-3555, National Dohme Research Laboratories, West Point, Virginia. wise pooled; the volume ranged from 1.5 to $6.0 \mathrm{ml}$ (mean for twelve specimens $4 \cdot 2 \mathrm{ml}$.).

Hypak disposable syringes (Becton Dickinson and Company), which were shown to contribute no detectable copper, were used in the collection of all specimens. Synovial fluid specimens with high viscosity were incubated with three turbidity reducing units (TRU) of testicular hyaluronidase per $\mathrm{ml}$. at $38^{\circ} \mathrm{C}$. for $4 \mathrm{hrs}$. It was demonstrated that hyaluronidase did not interfere with the analytical procedures. The specimens were centrifuged at 30,000 r.p.m. for $30 \mathrm{~min}$. to remove particulate matter and aliquots were analysed for copper and ceruloplasmin.

\section{Diagnosis of Rheumatoid Arthritis}

This was made on the basis of criteria established by the American Rheumatism Association (Ropes, Bennett, Cobb, Jacox, and Jessar, 1957). The patients were also classified as to stage of disease and functional status (Steinbrocker, Traeger, and Batterman, 1949).

\section{Semi-Quantitative Determination of Ceruloplasmin}

The presence of ceruloplasmin in synovial fluid was demonstrated by the column chromatographic-spectrophotometric method described by Deutsch (1960). Synovial fluid was digested with hyaluronidase, dialyzed against $0 \cdot 05 \mathrm{M}$ acetate buffer, $p \mathrm{H} 5 \cdot 5$, and passed over a column of DEAE cellulose. The ceruloplasmin was adsorbed near the top of the column in a narrow bluecoloured band. From visual inspection, it was apparent that more ceruloplasmin was adsorbed from rheumatoid synovial fluid than from the control fluid. Although the eluates reflected this difference when examined in a spectrophotometer at $610 \mu$, the elution procedure was not sufficiently reproducible to make this a useful method of quantitatıve analysis.

The presence of increased concentrations of ceruloplasmin in synovial fluid from patients with rheumatoid arthritis was also demonstrated by an immunodiffusion method, using glycine-buffered agar which contained antibody to human ceruloplasmin obtained from Hyland Laboratories (Immuno-Plates). 


\section{Quantitative Determination of Ceruloplasmin}

Ceruloplasmin was determined by a modification of the method of Scheinberg and Morell (1957) which is based on the observation that ceruloplasmin catalyses the oxidation of paraphenylenediamine (Holmberg and Laurell, 1951). Under carefully controlled conditions of temperature, $p \mathrm{H}$ and ionic concentration, the rate of the reaction is proportional to ceruloplasmin concentration, and the results are reproducible within limits of 3 per cent. A reference curve was prepared from rates of reactions obtained with solutions of purified ceruloplasmin. Ceruloplasmin concentration of the reference solutions was established from copper analysis of the purified preparation supplied by the American National Red Cross. Ceruloplasmin copper was calculated on the basis of the observation that ceruloplasmin contains 0.34 per cent. of copper (Holmberg and Laurell, 1951). Non-ceruloplasmin copper was calculated by subtracting ceruloplasmin copper from total copper concentration.

\section{Determination of Copper}

Copper was determined by the oxalydihydrazide method (Stark and Dawson, 1958; Gran, 1956) following ashing of the specimen with nitric and perchloric acids on a sand bath at $270^{\circ} \mathrm{C}$. for approximately $4 \mathrm{hrs}$. Reference solutions which contained between 1.0 and $10.0 \mu \mathrm{g}$. copper per $\mathrm{ml}$. were prepared from metallic copper (Stark and Dawson, 1958).

\section{Determination of Protein}

Total protein was determined by the method of Lowry, Rosebrough, Farr, and Randall (1951), and albumin and total globulin were determined by paper electrophoresis.

\section{Results}

The mean ceruloplasmin concentrations in synovial fluid from 23 patients with rheumatoid arthritis, twelve cadavers without evidence of rheumatic disease, and six "normal" volunteers were $23.8 \mathrm{mg}$. per cent. $(\mathrm{SD}=7 \cdot 4), 6 \cdot 1 \mathrm{mg}$. per cent. $(\mathrm{SD}=4 \cdot 2)$, and $4.3 \mathrm{mg}$. per cent. (SD $=1 \cdot 6$ ) respectively. These concentrations of ceruloplasmin are equivalent to $81 \mu \mathrm{g}$. copper $/ 100 \mathrm{ml} ., 21 \mu \mathrm{g}$. copper $/ 100 \mathrm{ml}$., and $15 \mu \mathrm{g}$. copper $/ 100 \mathrm{ml}$. respectively (Table I). Statistical evaluation revealed that the mean ceruloplasmin copper concentration in synovial fluid from patients with rheumatoid arthritis was significantly greater $(P<0.01)$ than that synovial fluid from either the cadavers or the "normal" volunteers. The mean concentrations of total copper in these specimens were $107 \mu \mathrm{g} . / 100 \mathrm{ml}$. $(\mathrm{SD}=22), 47 \cdot 7$ $\mu \mathrm{g} . / 100 \mathrm{ml} .(\mathrm{SD}=17)$, and $50 \cdot 0 \mu \mathrm{g} . / 100 \mathrm{ml}$. (SD $=$ 14) respectively. The mean copper concentration in synovial fluid from patients with rheumatoid arthritis was significantly greater $(P<0.01)$ than in that from either of the control groups. Mean concentrations of non-ceruloplasmin copper were 26 $\mu \mathrm{g} . / 100 \mathrm{ml}$. (SD $=14.5), 27 \mu \mathrm{g} . / 100 \mathrm{ml}$. (SD = $11 \cdot 6)$, and $35 \mu \mathrm{g} . / 100 \mathrm{ml}$. (SD $=13 \cdot 5)$ respectively.

The mean ceruloplasmin concentrations in blood serum from nineteen "normal" volunteers and 21 patients with rheumatoid arthritis were $36.4 \mathrm{mg}$./ $100 \mathrm{ml}$. (SD $=8 \cdot 5)$ and $46.3 \mathrm{mg} . / 100 \mathrm{ml}$. (SD = $10 \cdot 6)$ respectively. These concentrations of ceruloplasmin are equivalent to $124 \mu \mathrm{g}$. copper $/ 100 \mathrm{ml}$. and $157 \mu \mathrm{g}$. copper $/ 100 \mathrm{ml}$. respectively (Table II). The mean total copper concentrations in the same blood serum specimens were $148 \mathrm{~kg}$. $/ 100 \mathrm{ml}$. (SD = $25)$ and $192 \mu \mathrm{g}, / 100 \mathrm{ml}$. $(\mathrm{SD}=34)$ respectively, and mean non-ceruloplasmin copper concentrations were $24: \mathrm{kg} / 100 \mathrm{ml}$. and $35: \mathrm{kg} . / 100 \mathrm{ml}$. respectively.

TABLE I

COPPER AND CERULOPLASMIN CONCENTRATIONS IN SYNOVIAL FLUID FROM "NORMAL" VOLUNTEERS, CADAVERS, AND PATIENTS WITH RHEUMATOID ARTHRITIS

\begin{tabular}{|c|c|c|c|c|c|}
\hline \multirow[t]{2}{*}{ Series } & \multirow{2}{*}{ No. of Cases } & Ceruloplasmin & Ceruloplasmin Copper & Total Copper & $\begin{array}{l}\text { Non-Ceruloplasmin } \\
\text { Copper }\end{array}$ \\
\hline & & mg. per cent. $( \pm \mathrm{SD})$ & ug. per cent. $(\div$ SD) & ug. per cent. $( \pm S D)$ & $\mu$ g. per cent. $( \pm$ SD) \\
\hline "Normals" & 6 & $4 \cdot 3( \pm 1 \cdot 6)$ & $15( \pm 5 \cdot 7)$ & $50 \cdot 0( \pm 14)$ & $35( \pm 13 \cdot 5)$ \\
\hline Cadavers & 12 & $6 \cdot 1(\div 4 \cdot 2)$ & $21(\div 14 \cdot 4)$ & $47 \cdot 7(=17)$ & $27(=11 \cdot 6)$ \\
\hline Rheumatoid Arthritis & 23 & $23 \cdot 8( \pm 7 \cdot 4)$ & $81(=25 \cdot 3)$ & $107(=22)$ & $26( \pm 14 \cdot 5)$ \\
\hline
\end{tabular}

TABLE II

COPPER AND CERULOPLASMIN CONCENTRATIONS IN BLOOD SERUM FROM “NORMAL“ VOLUNTEERS AND PATIENTS WITH RHEUMATOID ARTHRITIS

\begin{tabular}{|c|c|c|c|c|c|}
\hline Series & No. of Cases & Ceruloplasmin & Ceruloplasmin Copper & Total Copper & $\begin{array}{c}\text { Non-Ceruloplasmin } \\
\text { Copper }\end{array}$ \\
\hline & & mg. per cent. ( $t$ SD) & ug. per cent. $(=$ SD) & :g. per cent. $(=\mathrm{SD})$ & «g. per cent. ( \pm SD) \\
\hline "Normals" & 19 & $36 \cdot 4( \pm 8 \cdot 5)$ & $124(: 29)$ & $148(=25)$ & $24( \pm 15 \cdot 6)$ \\
\hline Rheumatoid Arthritis & 21 & $46 \cdot 3(=10 \cdot 6)$ & $157(=36)$ & $192( \pm 34)$ & $35( \pm 25 \cdot 0)$ \\
\hline
\end{tabular}


Statistical evaluation of the data by the "Student's $t$ test" showed that none of the differences between the mean values for blood serum were significant $(P>$ $0 \cdot 05$ ).

Table III shows the distribution ratios of total copper, ceruloplasmin copper, and non-ceruloplasmin copper between simultaneously collected specimens of synovial fluid and blood serum from patients with rheumatoid arthritis compared with the "normal" controls. In the "normal" control subjects, the mean total copper concentration in synovial fluid was only about one-third as great as that in blood serum, but in the patients with rheumatoid arthritis, it exceeded half the mean value obtained for blood serum. The mean ceruloplasmin copper concentration in synovial fluid from the "normal" control subjects was only $0 \cdot 14$ times the concentration in blood serum, but in patients with rheumatoid arthritis it was raised to half the mean value obtained for blood serum. The non-ceruloplasmin copper concentration in synovial fluid is essentially the same as that in blood serum in "normal" control subjects, but is slightly less in synovial fluid than in blood serum of patients with rheumatoid arthritis.

The partition ratios of ceruloplasmin, total protein, albumin, and total globulin between blood serum and synovial fluid of patients with rheumatoid arthritis are compared in Table IV with those of the "normal" subjects. Relative to its concentration in blood serum, the concentration of ceruloplasmin in "normal" synovial fluid is markedly less than the concentrations of total protein, albumin, and total globulin. In patients with rheumatoid arthritis, however, the concentration of ceruloplasmin in synovial fluid is proportionately higher than that of the other proteins and its partition ratio between blood serum and synovial fluid in these patients approaches that of the other proteins.

\section{Discussion}

Other investigators (Evers, 1952) have reported raised blood serum copper levels in patients with rheumatoid arthritis and have suggested that this observation might serve as a useful criterion in the diagnosis of this disease (Durrigl, Ruzdic, and Subie, 1961). Although the mean copper and ceruloplasmin concentrations in blood serum from patients with rheumatoid arthritis were slightly raised in the present study, statistical evaluation of the data by the "Student's $t$ test" indicated that the differences observed were not significant $(P>0 \cdot 05)$. These studies confirm earlier observations that most of the copper in blood serum is present in the form of ceruloplasmin, and that the concentration of total copper normally reflects the concentration of the ceruloplasmin (Holmberg and Laurell, 1951).

TABLE III

DISTRIBUTION OF COPPER IN BLOOD SERUM AND SYNOVIAL FLUID IN "NORMAL" VOLUNTEERS AND PATIENTS WITH RHEUMATOID ARTHRITIS

\begin{tabular}{|c|c|c|c|c|c|c|c|}
\hline \multirow[b]{2}{*}{ Series } & \multirow[b]{2}{*}{$\begin{array}{c}\text { No. } \\
\text { of } \\
\text { Cases }\end{array}$} & \multicolumn{2}{|c|}{ Total Copper } & \multicolumn{2}{|c|}{ Ceruloplasmin Copper } & \multicolumn{2}{|c|}{ Non-Ceruloplasmin Copper } \\
\hline & & $\mu \mathrm{g}$. per cent. $(=\mathrm{SD})$ & Ratio $\frac{\text { SF }}{\text { BS }}$ & $\mu$ g. per cent. $(+$ SD $)$ & Ratio $\frac{\text { SF }}{\text { BS }}$ & ug. per cent. ( $=\mathrm{SD})$ & Ratio $\frac{\mathrm{SF}}{\mathrm{BS}}$ \\
\hline $\begin{array}{l}\text { "Normals" } \\
\text { Blood Serum } \\
\text { Synovial Fluid }\end{array}$ & 6 & $\begin{array}{r}140( \pm 23) \\
50( \pm 14)\end{array}$ & $0 \cdot 36$ & $\begin{array}{l}106( \pm 28) \\
15( \pm 5 \cdot 7)\end{array}$ & $0 \cdot 14$ & $\begin{array}{l}34(t 17) \\
35( \pm 14)\end{array}$ & $1 \cdot 03$ \\
\hline $\begin{array}{l}\text { Rheumatoid Arthritis } \\
\text { Blood Serum } \\
\text { Synovial Fluid }\end{array}$ & 19 & $\begin{array}{l}196(\mp 32) \\
107( \pm 21)\end{array}$ & $0 \cdot 54$ & $\begin{array}{r}160( \pm 36) \\
81( \pm 28)\end{array}$ & $0 \cdot 50$ & $\begin{array}{l}36( \pm 25) \\
27( \pm 16)\end{array}$ & $0 \cdot 75$ \\
\hline
\end{tabular}

TABLE IV

COMPARISON OF PARTITION OF TOTAL PROTEIN, ALBUMIN, TOTAL GLOBULIN, AND CERULOPLASMIN BETWEEN BLOOD SERUM AND SYNOVIAL FLUID OF “NORMAL" VOLUNTEERS AND PATIENTS WITH RHEUMATOID ARTHRITIS

\begin{tabular}{|c|c|c|c|c|c|c|c|c|c|}
\hline \multirow{2}{*}{ Series } & \multirow[b]{2}{*}{$\begin{array}{l}\text { No. } \\
\text { of } \\
\text { Cases }\end{array}$} & \multicolumn{2}{|c|}{ Total Protein } & \multicolumn{2}{|c|}{ Albumin } & \multicolumn{2}{|c|}{ Total Globulin } & \multicolumn{2}{|c|}{ Ceruloplas min } \\
\hline & & Per cent. & Ratio $\frac{\mathrm{SF}}{\mathrm{BS}}$ & Per cent. & Ratio $\frac{\mathrm{SF}}{\mathrm{BS}}$ & Per cent. & Ratio $\frac{\text { SF }}{\mathrm{BS}}$ & mg. Per cent. & Ratio $\frac{\mathrm{SF}}{\mathrm{BS}}$ \\
\hline $\begin{array}{l}\text { "Normals" } \\
\text { Blood Serum } \\
\text { Synovial Fluid }\end{array}$ & 6 & $\begin{array}{l}8 \cdot 4 \\
2 \cdot 2\end{array}$ & $0 \cdot 26$ & $\begin{array}{l}4 \cdot 7 \\
1 \cdot 4\end{array}$ & $0 \cdot 30$ & $\begin{array}{l}3 \cdot 7 \\
0 \cdot 8\end{array}$ & $0 \cdot 22$ & $\begin{array}{r}31 \cdot 1 \\
4 \cdot 3\end{array}$ & $0 \cdot 14$ \\
\hline $\begin{array}{c}\text { Rheumatoid Arthritis } \\
\text { Blood Serum } \\
\text { Synovial Fluid }\end{array}$ & 19 & $\begin{array}{l}7 \cdot 9 \\
4 \cdot 9\end{array}$ & $0 \cdot 62$ & $\begin{array}{l}4 \cdot 3 \\
2 \cdot 6\end{array}$ & $0 \cdot 61$ & $\begin{array}{l}3 \cdot 7 \\
2 \cdot 1\end{array}$ & $0 \cdot 57$ & $\begin{array}{l}46 \cdot 3 \\
23 \cdot 8\end{array}$ & $0 \cdot 51$ \\
\hline
\end{tabular}


Ceruloplasmin has previously been identified in synovial fluid by immuno-electrophoresis (Schmid and MacNair, 1956), but quantitative studies have not been reported. The present studies clearly indicate that the concentration of total copper in synovial fluid is raised by a factor of approximately two in patients with rheumatoid arthritis when compared with that in "normal" volunteers, and that essentially all of this increase is accounted for by an increase in ceruloplasmin, there bəing no significant difference in non-ceruloplasmin copper concentrations.

The concentration of total copper in synovial fluid from normal subjects is about 64 per cent. less than that in blood serum. Approximately 30 per cent. of the total copper is present in the form of ceruloplasmin and 70 per cent. in the form of nonceruloplasmin copper. The total copper concentrations in synovial fluid from patients with rheumatoid arthritis is only 50 per cent. less than that in blood serum. Approximately 76 per cent. of the total copper is in the form of ceruloplasmin and only 24 per cent in the form of non-ceruloplasmin copper.

The concentration of ceruloplasmin in normal synovial fluid, relative to its concentration in blood serum, is less than that of total protein, albumin, or total globulin. The ratio of its concentration in synovial fluid to its concentration in blood serum is about 50 per cent of that for total protein. If as is generally believed, the proteins of synovial fluid arise from blood serum, the results of the present study indicate that the synovial membrane is normally relatively impermeable to ceruloplasmin. Although the total protein concentration in synovial fluid from patients with rheumatoid arthritis is raised, the increase in ceruloplasmin concentration is proportionately greater than that in total protein, albumin, or total globulin. In these patients, the ratio of ceruloplasmin concentration in synovial fluid to its concentration in blood serum approaches the values for total protein, albumin, and total globulin. It was recently reported (Neidermeier, Cross, and Beetham, 1965) that haptoglobin, which like ceruloplasmin is an alpha-2 glycoprotein, is also increased to a greater degree than total protein or albumin in synovial fluid from patients with rheumatoid arthritis. It would thus appear that both of these glycoproteins are normally selectively excluded from synovial fluid, and that, in patients with rheumatoid arthritis, the synovial membrane loses its capacity to discriminate against them. The nature of the permeability of the synovial membrane is not well understood, and represents a difficult problem, since the concept of a synovial membrane departs from the anatomical concept in that true cell-to-cell continuity does not exist as is generally found in other membranes. Recent studies (Nettelbladt, Sundblad, and Jonsson, 1963), however, indicate that the entry of proteins into the synovial space may be a highly selective process in which molecular weight is of secondary importance.

Studies are at present in progress to determine whether changes described in ceruloplasmin concentration in synovial fluid are specific for patients with rheumatoid arthritis, or whether similar changes also accompany joint effusions associated with trauma and osteo-arthritis.

In the present studies, there was no obvious correlation between the total copper or ceruloplasmin concentration in blood serum or synovial fluid and the functional status, clinical stage, or medication which the patient was receiving at the time of aspiration, although the ceruloplasmin concentrations in synovial fluid appeared to be approximately parallel with the duration of the disease. It has been reported (Lipkin, Herrmann, and Mandol, 1962) that the administration of adrenocortical steroids results in a lowering of blood serum ceruloplasmin levels. These observations could not be confirmed in the present study because of the small number of patients included in our series who were receiving steroid medication.

\section{Summary}

Total copper and ceruloplasmin concentrations were determined in blood serum and synovial fluid from patients with rheumatoid arthritis, and the mean values contrasted with those obtained from "normal" volunteers and from cadavers without evidence of rheumatic disease. The increase in ceruloplasmin concentration in synovial fluid from patients with rheumatoid arthritis was confirmed by three different methods of analysis, each based on a different property of the protein.

The results of these studies demonstrated that:

(1) The concentration of copper in synovial fluid from patients with rheumatoid arthritis was markedly raised. Approximately 76 per cent. of the total copper represented ceruloplasmin which accounted entirely for the increase in total copper concentration.

(2) The concentration of copper in synovial fluid from "normal" volunteers was only about 36 per cent. as great as that in their blood serum; 30 per cent. of the copper in "normal" synovial fluid was in the form of ceruloplasmin.

(3) The non-ceruloplasmin copper concentration in synovial fluid was essentially the 
same as that in blood serum from both "normal" volunteers and patients with rheumatoid arthritis.

(4) The mean copper and ceruloplasmin concentrations in blood serum were slightly raised in patients with rheumatoid arthritis, but when the data were analysed statistically, the increase above the mean values for normal subjects was not significant.

The author wishes to thank Dr. James H. Pert of the American National Red Cross and Mr. Henrik Bjorling of A. B. Kabi for making purified ceruloplasmin preparations available and Mr. Kingdon Lou of Hyland Laboratories for making "Immuno-Plates" available for these studies. The competent technical assistance of Miss Esther Lacey and the co-operation of Drs. H. L. Holley, William P. Beetham, and Max Wilson for their clinical evaluation of the patients and for providing specimens of blood serum and synovial fluid for analysis are also acknowledged.

\section{REFERENCES}

Deutsch, H. F. (1960). Clin. Chim. Acta, 5, 460.

Durrigl, T., Ruzdic, I., and Subie, N. (1961). "Atti del IX Congresso della Lega Internazionale contro il Reumatismo", 2, 144.

Evers, A. (1952). Z. Rheumaforsch., 11, 164.

Gran, G. (1956). Anal. Chim. Acta, 14, 150.

Holmberg, C. G., and Laurell, C. B. (1951). Scand. J. clin. Lab. Invest., 3, 103.

Lipkin, G., Herrmann, F., and Mandol, L. (1962). J. invest. Derm., 39, 547.

Lowry, O. H., Rosebrough, N. J., Farr, A. L., and Randall, R. J. (1951). J. biol. Chem., 193, 265.

Nettelbladt, E., Sundblad, L., and Jonsson, F. (1963). Acta rheum. scand., 9, 28.

Niedermeier, W., Creitz, E. E., and Hollev, H. L. (1962). Arthr. and Rheum., 5, 439.

, Cross, R., and Beetham, W. P., Jr. (1965). Ibid.,

8, 355 .

Ropes, M. W., Bennett, G. A., Cobb, S., Jacox, R., and Jessar, R. A. (1957). J. chron. Dis., 5, 630.

Scheinberg, I. H., and Morell, A. G. (1957). Ibid., 36, 1193.

Schmid, A., and MacNair, M. B. (1956). J. clin. Invest., 35, 814 .

Stark, G. R., and Dawson, C. R. (1958). Anal. Chem., 30, 191.

Steinbrocker, O., Traeger, C. H., and Batterman, R. C. (1949). J. Amer. med. Ass., 140, 659.

La concentration et l'état chimique du cuivre dans le liquide synovial et le sérum sanguin des malades atteints d'arthrite rhumatismale

RÉSUMÉ

On détermina les concentrations totales du cuivre et de la céruloplasmine dans le sérum sanguin et le liquide synovial des malades atteints d'arthrite rhumatismale. Les taux moyens contrastaient avec ceux obtenus chez des volontaires "normaux" et chez des cadavres sans signes de maladie rhumatismale. L'augmentation du taux de la céruloplasmine dans le liquide synovial des malades atteints d'arthrite rhumatismale fut confirmée par trois méthodes analytiques différentes, chacune basée sur une properté différente de la protéine.

Les résultats de ces études montrent que:

1. Le taux du cuivre dans le liquide synovial des malades atteints d'arthrite rhumatismale était nettement augmenté. Près de $76 \%$ du cuivre total représentait la céruloplasmine qui était entièrement reponsable de l'augmentation du taux cuprique total.

2. Le taux du cuivre dans le liquide synovial des volontaires "normaux" n'était que $36 \%$ de leur taux sanguin. Chez ces témoins $30 \%$ du cuivre du liquide synovial appartenait à la céruloplasmine.

3. En dehors de la céruloplasmine, le taux cuprique du liquide synovial et du sérum sanguin était essentiellement le même, tant chez les témoins que les rhumatisants.

4. Les valeurs moyennes du cuivre et de la céruloplasmine dans le sérum sanguin étaient légèrement augmentées chez les malades atteints d'arthrite rhumatismale, mais cette augmentation, par rapport aux valeurs moyennes normales, n'était pas statistiquement significative.

La concentración y el estado químico del cobre en el líquido sinovial y en el suero sanguíneo de enfermos coß artritis reumatoide

\section{Sumario}

Se determinaron las concentraciones totales del cobre y de la ceruloplasmina en el suero sanguíneo y el líquido sinovial de enfermos con artritis reumatoide. Las cifras medias contrastaban con las obtenidas en voluntarios "normales" y en cadáveres sin evidencia de enfermedad reumatoide. La aumentación de la cifra de ceruloplasmina en el liquido sinovial de enfermos con artritis reumatoide fué corroborada por tres métodos analíticos diferentes, basados en propiedades diferentes de la proteina.

Los resultados de esta investigación muestran que:

1. Las cifras del cobre en el líquido sinovial de enfermos con artritis reumatoide fueron marcadamente aumentadas. Cerca de un $76 \%$ del cobre total formaba parte de la ceruloplasmina, que fué enteramente responsable del aumento de la cifra total de este metal.

2. Las cifras del cobre en el líquido sinovial de los voluntarios "normales" fueron sólo un $36 \%$ de los valores sanguíneos de estos. En estos testigos un $30 \%$ del cobre del líquido sinovial pertenecía a la ceruloplasmina.

3. Fuera de la ceruloplasmina, las cifras del cobre del liquido sinovial y de la sangre fueron esencialmente idénticas, tanto en los testigos como en los reumáticos.

4. Los valores medios del cobre y de la ceruloplasmina en el suero sanguíneo fueron algo aumentados en los enfermos con artritis reumatoide, pero este aumento, comparado con los valores medios normales no tuvo significación estadistica. 